\title{
Ny metode forbedrer vurderingen av rektumkreft
}

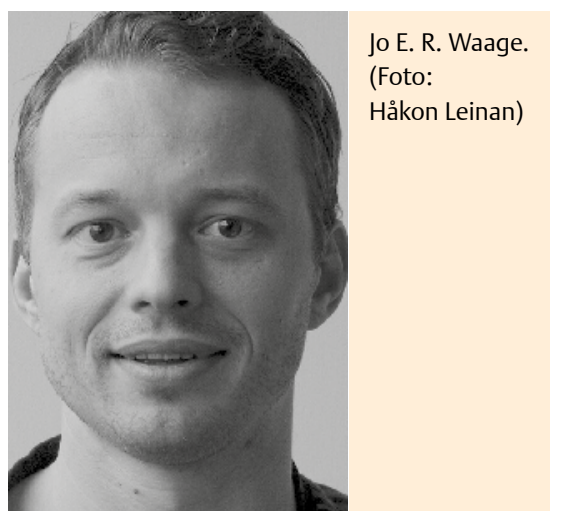

Jo Erling Riise Waage disputerte torsdag 2. oktober 2014 for ph.d.-graden ved Universitetet i Bergen med avhandlingen:

"Strain elastography evaluation of rectal tumours - a critical assessment of a new imaging modality".

Rektumcancer er en av de hyppigste kreftformene i Norge med økende forekomsten. Hvilken behandlingsform en velger er avhengig av tumorstadiet. Det er derfor avgjørende å bestemme tumorstadiet så presist som mulig.

Avhandlingens fem studier har vært rettet mot å evaluere den nye metoden elastografi for vurdering av rektumtumorer. Metoden måler hardhet i svulstene og det omliggende vevet ved hjelp av ultralyd.

Studie 1 dannet grunnlaget for hvordan målingene ble gjennomført på pasienter i de påfølgende fire studiene. Studie 2 inkluderte 69 pasienter og viste, at metoden kan benyttes som en del av en standard poliklinisk utredning av pasienter med nyoppdaget rektumkreft. Studie 3-5 viste på 120 nye pasienter, at elastografi sannsynligvis kan forbedre vurderingen av disse pasientene. Verdien er størst når det gjelder å skille mellom godartede svulster, tidlige ondartede svulster og mer avanserte ondartede svulster. Det foreslås en vurderingsalgoritme, men funnene bør bekreftes gjennom en større multisenterstudie, før den kan anbefales som en del av standard utredning. 